\title{
Evaluation of a MBBR (moving bed biofilm reactor) pilot plant for treatment of pulp and paper mill wastewater
}

\author{
Daniel Vieira Minegatti de Oliveira ${ }^{1,}$, Marcio Dias Rabelo ${ }^{2}$, Yuri Nascimento Nariyoshi ${ }^{3}$ \\ ${ }^{1}$ Environmental Engineer by UFV, M. Sc. in Technology in Environmental Sanitation and Water by COPPE/UFRJ, Doctoral Student at \\ Departerment of Hydraulics and Sanitary Engineering, USP/SP. Technical Director at MMA Consultoria Ambiental, São Paulo, Brazil \\ ${ }^{2} \mathrm{M}$. Sc. in Chemistry at Federal University of Viçosa, UFV, Viçosa - Brazil \\ ${ }^{3}$ Chemical Engineer by UFES, Doctoral Student at Departerment of Chemical, USP/SP, São Paulo - Brazil
}

Email address:

daniel.minegatti@gmail.com (D. V. M.d. Oliveira)

\section{To cite this article:}

Daniel Vieira Minegatti de Oliveira, Marcio Dias Rabelo, Yuri Nascimento Nariyoshi. Evaluation of a MBBR (Moving Bed Biofilm Reactor) Pilot Plant for Treatment of Pulp and Paper Mill Wastewater. International Journal of Environmental Monitoring and Analysis. Vol. 2, No. 4, 2014, pp. 220-225. doi: 10.11648/j.ijema.20140204.15

\begin{abstract}
Moving Bed Biofilm Reactor (MBBR) process is a technology for the wastewater treatment that incorporates the best characteristics of processes with growth of biomass in suspension and adhered biomass (biofilm). Therefore, it is possible to maintain a higher amount of biomass in the same biological reactor and thus add a larger amount of substrate for biodegradation. The main aim of this paper was to characterize the adhered biomass to the carriers and evaluate the operational parameters and performance of a pilot-scale MBBR for the treatment of a pulp and paper mill wastewater, after preliminary treatment, the primary decanting, the $\mathrm{pH}$ adjustment, addition of nutrients, cooling and, thermophilic conditions. The pilot plant was operated within the limits recommended by literature in relation the Volumetric and Superficial Organic loads (VOL and SOL), respectively of $4.3 \mathrm{~kg}_{\text {soluble }} \mathrm{BOD} \mathrm{m} \mathrm{m}^{-1} \mathrm{~d}^{-1}$ and $43.8 \mathrm{~g}_{\text {soluble }} \mathrm{BOD} \mathrm{m} \mathrm{m}^{-2}$, equal to the lower limit recommended considering the concentration of dissolved oxygen (DO) of $2 \mathrm{mg} \mathrm{L}^{-1}$ and carriers volume equal to $10 \%$ of the reactor volume. May be detached regarding the process performance that the removal efficiencies of Soluble Biochemical Oxygen Demand (soluble BOD) and Soluble Chemical Oxygen Demand (soluble $\mathrm{COD}$ ) obtained were respectively, 56 and $35 \%$, and that process remained fairly stable under these conditions work and in no time during this study was observed clogging/fouling of carriers.
\end{abstract}

Keywords: Moving Bed Biofilm Reactor, Operational and Performance Evaluation, Pulp and Paper Wastewater

\section{Introduction}

Pulp and Paper Mills use in their processes large amounts of water and thus generate large quantities of effluents, approximately 30 to $60 \mathrm{~m}^{3}$ per ton of pulp. These effluents are rich in dissolved organic matter (soluble BOD and COD), which gives them a huge potential for pollution if not properly treated.

Moving Bed Biofilm Reactor (MBBR) process consists in a technology that is gaining market and application for treatment of effluent, which incorporates the best characteristics of processes with growth of biomass in suspension and adhered biomass (biofilm) (RUSTEN et al., 1994).

Inside the MBBR reactor, carriers are introduced for adhesion of microbial decomposers, thus forming the biofilm. These carriers are held in suspension by agitation promoted by aeration system of coarse or medium bubbles, favoring the absorption of oxygen by the collapse of these bubbles in fine bubbles, providing high mobility to the carriers, and consequently exposure and contact with the net mass in suspension (MINEGATTI, 2008).

The reason for the use of the carriers in biological reactor is the creation of a surface area for biomass growth and to an increased cell retention time. The higher concentration of solids maintained adhered and in suspension allows increasing the capacity of decomposition of organic matter and the conversion of nitrogen compounds, if appropriate.

The control variables are the same applied to the activated sludge process, maintaining the specificity that 
the concentration of biological solids in the reactor is also due to the biomass adhered to the carriers and therefore there is a relationship between the volume of the support medium and the aeration tank. In the control of reactors with adhered biomass, it is customary to relate the organic load applied to the biological reactor with the total surface area of the carriers, here called Superficial Organic Loading (SOL), expressed in $\mathrm{g}$ DBO m $\mathrm{m}^{-2} \cdot \mathrm{d}^{-1}$, which is the parameter that can be best associated with the process.

Among the main advantages of this technology is the attainment of compact systems, resistant to peak organic loads and peak hydraulic loads, and variations of $\mathrm{pH}$ and temperature; non-occurrence of clogging (fouling) of the carriers (ODEGAARD et al., 1994). However, such advantages were always observed when the reactor was working as the first reactor of the biological treatment. This is due to the fact that this process usually employs low Hydraulic Retention Time (HRT) of about 3 hours, implying at low periods for that the microorganisms can degrade the substrate, thus being able to only consume the organic matter easily biodegradable (soluble BOD and COD).

The material used for the manufacture of the carriers is usually polyethylene or polypropylene, whose density ranges from 0.95 to $0.99 \mathrm{~g} \mathrm{~cm}^{-3}$; diameter between 10 and $45 \mathrm{~mm}$ and a width between 7 and $30 \mathrm{~mm}$ have been employed. Some kinds of carriers currently employed in the MBBR process are shown in Figure 1.

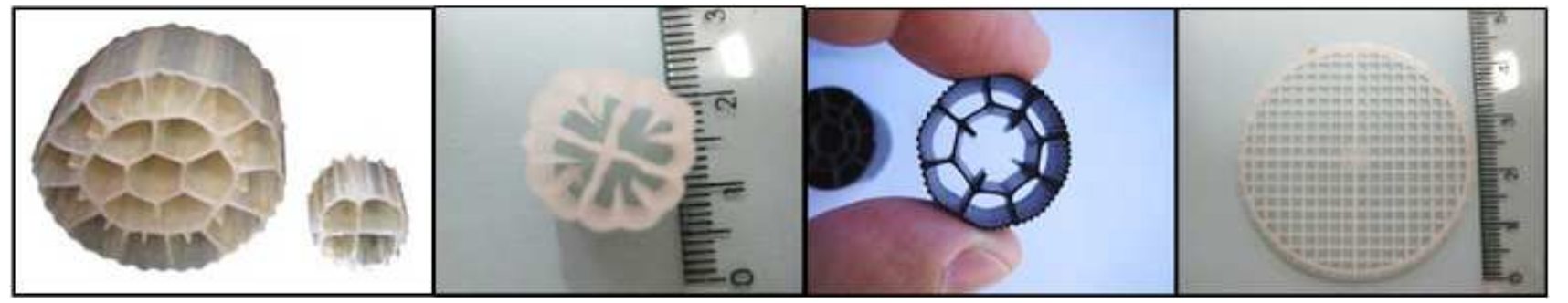

Figure 1. Models of carriers employed in the MBBR process

Different configurations carriers result in different contact areas, which may present higher or lower potential for adhesion of biomass due to the geometric design and arrangement of the piece/carrier. The specific surface area of the carrier found on the market range from 350 to 1000 $\mathrm{m}^{-2} \mathrm{~m}^{-3}$ (MINEGATTI, 2008).

The volume of the carrier is usually inserted into the reactor from $20 \%$ to $70 \%$ of the volume thereof. For lower densities than $20 \%$, there is a loss in the efficiency of oxygen transfer due to the lack of material to effect the reduction of the sizes of air bubbles introduced by aeration system. To densities exceeding $70 \%$, it becomes uneconomical, since a high amount of biomass requires high energy expenditure in both the mixing of the carriers and the supply of oxygen (RUSTEN et al., 1998). The Technical Standard NBR 12,209 of the Brazilian Association of Technical Standards (ABNT) recommends keeping in the reactor a concentration of Dissolved Oxygen (DO) in $3.0 \mathrm{mg} \mathrm{L}^{-1}$, to meet these requirements.

Within the pulp and paper mills, we can highlight some mills that use this process for the wastewater treatment as Klabin and Suzano in Brazil and Stora Papyrus Grycksbo $\mathrm{AB}$, Stora Cell Industri AB, Stora Fors Billerud AB and Norske Sande Skog Paper Mill A/S in Sweden (RUSTEN et al., 1994). Specialized literature reports some results of the MBBR process with regard to the wastewater treatment from pulp and paper mills.

Jahren et al., (2002) have worked with a MBBR on a laboratory scale with $58 \%$ of volume carriers, which had a specific surface area of $350 \mathrm{~m}^{-2} \mathrm{~m}^{-3}$. The DO concentration was maintained between 2 and $3 \mathrm{mg} \mathrm{L}^{-1}, \mathrm{pH}$ between 8.0 to 8.5 and HRT was decreased gradually up to 30 to 14 hours.

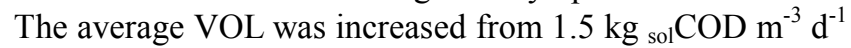

to a maximum of $3.8 \mathrm{~kg}$ sol $\mathrm{COD} \mathrm{m} \mathrm{m}^{-3} \mathrm{~d}^{-1}$. It is noteworthy that the experimental apparatus did not contain the secondary settling tank. However, the main objective of the study was to evaluate the influence of temperature on the removal of soluble $\mathrm{COD}$, ie, the temperature remained around $55^{\circ} \mathrm{C}$ (thermophilic conditions). Thereby, it was achieved an efficiency of removal of soluble COD and soluble $\mathrm{BOD}_{5}$ and, respectively, 60 to $65 \%$ and 70 to $75 \%$. It is also mentioned that in mesophilic conditions (temperature $\approx 30^{\circ} \mathrm{C}$ ), average soluble COD removal efficiency was $80 \%$, demonstrating the influence of temperature on the removal of organic matter.

Broch-Due et al., (1997) conducted tests in pilot scale, including three different effluents from a pulp and paper mill, with VOL (Volumetric Organic Load) between 2.5 and $26.9{ }_{\text {sol }} \mathrm{COD} \mathrm{m} \mathrm{m}^{-3} \cdot \mathrm{d}^{-1}$. In all tests, the experimental apparatus consisted of two MBBR in series followed by a secondary settling vessel, which had no recycled sludge. Both MBBR were $70 \%$ filled with carriers, which had a specific surface area of $500 \mathrm{~m}^{-2} \mathrm{~m}^{-3}$. In all tests, $\mathrm{pH}$ was maintained at about 7.0, temperature ranged from 23 to $35{ }^{\circ} \mathrm{C}$, DO concentration was maintained between 2.5 to $5.7 \mathrm{mg} \mathrm{L}^{-1}$ and HRT ranged from 2.5 to 30 hours. The soluble COD and soluble $\mathrm{BOD}_{7}$ removal efficiency obtained was 54 to $82 \%$ and 62 to $80 \%$, respectively. Moreover, they observed that the higher HRT and temperature were, the higher was the process efficiency.

Rusten et al., (1994) developed four separate experiments (in pilot scale) treating effluent from pulp and paper mills located in Sweden, with VOL values ranging between 2.7 and $70 \mathrm{~kg}$ filtered BOD m$~^{-3} \cdot \mathrm{d}^{-1}$, which showed

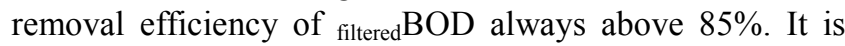
noteworthy that in all experiments it was necessary to 
correct the $\mathrm{pH}$ to about 7.0 , the temperature to about $30^{\circ} \mathrm{C}$ and nutrients, and the concentration of DO was kept above $3.0 \mathrm{mg} \mathrm{L} \mathrm{L}^{-1}$. In addition, it was always used volumes of carriers reaching $38 \%$ to $67 \%$ of the reactor volume, with HRT varying from 0.8 to 25 hours, and the systems were composed of two, three or four reactors in series. These authors also reported that SOL (Superficial Organic Load) applied in the treatment of pulp and paper effluents should be less than $50 \mathrm{gDBO}_{5} \mathrm{~m}^{-2} \mathrm{~d}^{-1}$ to obtain an overall efficiency (MBBR followed by another secondary treatment) of BOD above $70 \%$.

This work was developed in the company Suzano Papel e Celulose - Mucuri/Brazil, where the effluent treatment system consists of an aerated lagoon followed by three MBBR reactors in series with total HRT, respectively equal to 5.5 days and 3.0 hours and a volume of carriers equal to $10 \%$ of the reactor volume and subsequently the effluent flows into a settling pond. However, the MBBR process has been going practically since its implementation (in 2007) for instability in relation to the organic matter removal and the occurrence of fouling/clogging of the carriers. These facts can be previously explained by the position of the MBBR, i.e., biological treatment end unit (post-treatment of the aerated lagoon system).

Therefore, in order to investigate such events, the MBBR pilot plant was installed before the aerated lagoon and after the nutrient addition, working with average HRT of 3.3 hours and carriers volume equal to $10 \%$ of the reactor volume, similarly to the original process.

Thus, the present study aims to characterize the biomass adhered to the carriers, and assess the operational parameters and performance of a pilot MBBR in the treatment of the effluent from a pulp and paper mill in thermophilic conditions (average temperature of $44^{\circ} \mathrm{C}$ ).

\section{Methodology}

The experimental unit used consists in a pilot-scale MBBR installed in parallel to Suzano Papel e Celulose's WTP (Wastewater Treatment Plant), at Mucuri City Brazil. The effluent to be treated in the reactor passes initially by a primary treatment, which comprises the following steps: screening, primary sedimentation, $\mathrm{pH}$ adjustment, addition of nutrients and cooling. After initial treatment, the effluent sent to the biological treatment is pumped into the pilot MBBR.

Figure 2 shows a schematic drawing of the unit composed of the experimental apparatus having the following features:

- $\quad$ Diameter: $2.65 \mathrm{~m}$;

- Depth: 3.6 m;

- Usable volume: $20 \mathrm{~m}^{3}$;

- Airflow rate (minimum): $3.0 \mathrm{~m}^{3} \mathrm{~min}^{-1}$;

- DO: 2 to $3 \mathrm{mg} \mathrm{L}^{-1}$.

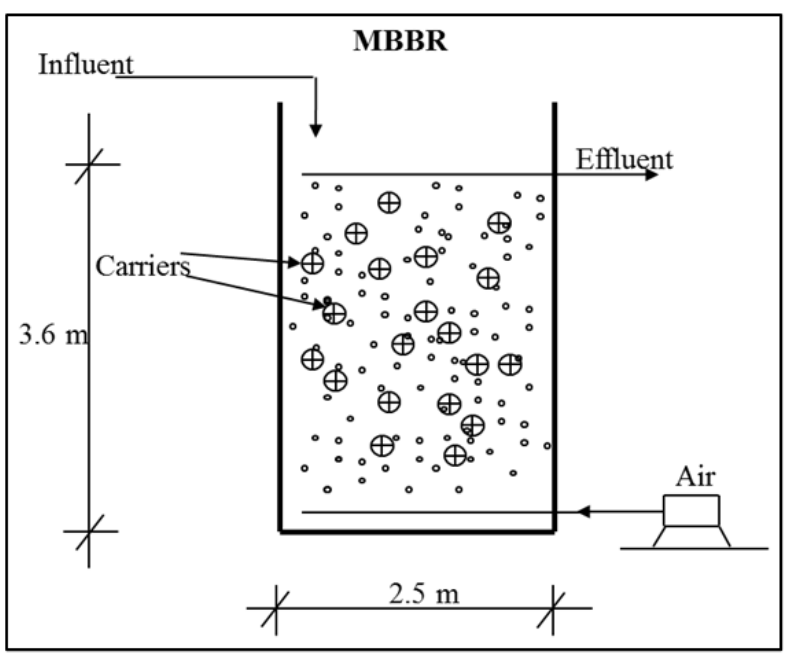

Figure 2. Schematic drawing of the pilot scale

The pilot plant was put into operation with average flow of $6.2 \mathrm{~m}^{3} \mathrm{~h}^{-1}$ and therefore average HRT of 3.3 hours and a volume of carriers (Biofil Chip ${ }^{T M}-P-$ Figure 3 ) at $10 \%$ of the reactor volume equal to $2.0 \mathrm{~m}^{3}$ in thermophilic conditions (average temperature of $44^{\circ} \mathrm{C}$ ) and $\mathrm{pH}$ ranging between 6.5 and 8.5 .

However, the pilot plant worked with a lower ratio COD/BOD (greater biodegradability), equal to 2.3 , due to the fact that it was the first unit of biological treatment, unlike the MBBR system installed at Suzano.

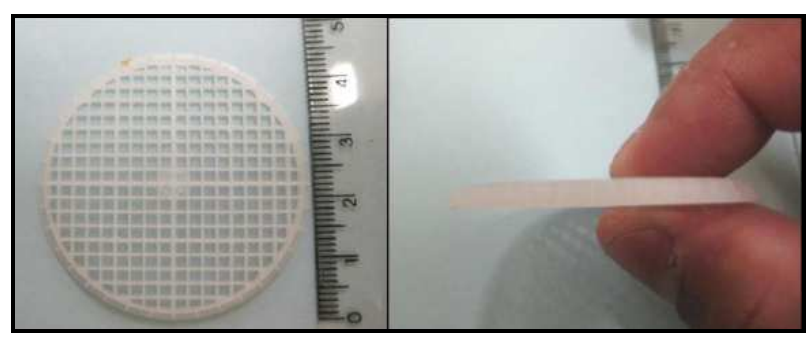

Figure 3. Picture of Chip-P from Biofilm of AnoxKaldnes ${ }^{\text {TM }}$ Corporation

The Pilot plant was monitored for 3 months according to the main parameters (soluble COD and $\mathrm{BOD}_{5}, \mathrm{TOC}, \mathrm{pH}$, Temp., etc.) according Standards Methods of Water and Wastewater Examination (APHA, 2005), in order to analyze mainly the positioning of MBBR system, the influence of the temperature on the process efficiency and performance of the carriers related to fouling.

The evaluation of the adhered biomass, as in any biological process for wastewater treatment occurs through means of the quantification of volatile solids, usually expressed according to the Volatile Suspended Solids (VSS). Therefore, the methodology that was applied, called "Cleaning/Washing + liquid Mass" (MINEGATTI, 2008), which can be described as follows:

- To remove randomly 25 carriers from the reactor, and put them together in a container containing the volume of $250 \mathrm{~mL}$ of distilled water, and concerning to preserve the liquid mass present inside the carriers; 
- To close and shake the container in order to release/detach the adhered solids;

- To Transfer the whole liquid mass to another container;

- $\quad$ To reintroduce new volume of $250 \mathrm{~mL}$ of distilled water in the container containing the carriers and to repeat the same procedures above, in order to remove of the solids mass that may still being adherent to the carriers;

- $\quad$ To gather into one volume of $500 \mathrm{~mL}$ of total liquid mass and from this one, calculate the solids mass (total, fixed, and volatile) as described (APHA, 2005).

The operating and control parameters observed throughout the experiment were achieved by analyzing the concentrations of BOD and COD and the values of $\mathrm{DO}, \mathrm{pH}$ and temperature.

It is understood that the VOL is the ratio of the organic load applied to the biological reactor and it volume, given

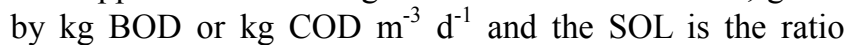
between the organic load applied and the total surface area due to the carriers in which arises as a particular control parameter of MBBR process - expressed in $\mathrm{g} B O D$ or COD $\mathrm{m}^{-2} \cdot \mathrm{d}^{-1}$.
Thus, it was obtained values between 5.7 and $13 \mathrm{~kg}$ ${ }_{\text {sol }}$ COD m $\mathrm{m}^{-3} \mathrm{~d}^{-1}$ (2.1 to $5.4 \mathrm{~kg}_{\text {sol }}$ BOD m $\left.\mathrm{m}^{-3} \mathrm{~d}^{-1}\right)$, resulting in an average VOL of $10.0 \mathrm{~kg}_{\text {sol }} \mathrm{COD} \mathrm{m} \mathrm{m}^{-3} \mathrm{~d}^{-1}$ and $4.3 \mathrm{~kg}_{\text {sol }} \mathrm{COD}$ $\mathrm{m}^{-3} \mathrm{~d}^{-1}$. In other hand, the values of SOL found ranged between 20.7 to $54.5 \mathrm{~g}_{\text {sol }} \mathrm{BOD} \mathrm{m} \mathrm{m}^{-2} \mathrm{~d}^{-1}$, resulting in an average value of $43.8 \mathrm{~g}_{\text {sol }}$ BOD m $\mathrm{m}^{-2} \mathrm{~d}^{-1}$.

The biological reactor temperatures ranges between 37.5 and $48.0{ }^{\circ} \mathrm{C}$, DO concentration were comprehended between 0.7 and $4.3 \mathrm{mg} \mathrm{L}^{-1}$ and the average $\mathrm{pH}$ influent to the reactor was 7.4 and the effluent was equal to 7.9 .

\section{Results and Discussion}

The results and subsequent discussion are organized to first characterize the biomass adhered to the carriers and then evaluate the performance of the process through operating conditions imposed.

\subsection{Characteristics of Adhered Biomass}

Table 1 shows the values of Solids Adhered Mass (called as Adhered Biomass Formation - ABF) in relation to the Total Suspended Solids (TSS) and VSS, expressed in $\mathrm{g} \mathrm{m}^{-2}$, obtained with the use of the methodology mentioned above.

Table 1. ABF to the carriers $\left(\mathrm{g} \mathrm{m}^{-2}\right)$

\begin{tabular}{|c|c|c|c|c|c|c|c|c|c|}
\hline \multirow{2}{*}{ Solids } & \multirow{2}{*}{ No. of tests } & \multirow{2}{*}{ Average } & \multirow{2}{*}{ Standard Deviation } & \multirow{2}{*}{ Coefficient of Variation } & \multicolumn{5}{|c|}{ Percentiles } \\
\hline & & & & & 10 & 25 & 50 & 75 & 90 \\
\hline TSS & 3 & 21.2 & 6.9 & 0.33 & 17.1 & 17.2 & 17.5 & 23.3 & 26.9 \\
\hline VSS & 3 & 14.6 & 5.0 & 0.34 & 11.4 & 11.7 & 12.2 & 16.2 & 18.7 \\
\hline
\end{tabular}

Note: It is understood as percentiles, a value corresponding to the "nth" cumulative frequency, i.e., the 25 th percentile is the first quartile, and the median is the $50^{\text {th }}$ percentile.

It is noted that although only three analyzes, the values indicate a high concentration of $\mathrm{ABF}$ to the carriers, because the NBR 12.209 of ABNT recommends values up to $12 \mathrm{~g} \mathrm{VSS} \mathrm{m}^{-2}$ and it is present in literature values from 4 $\mathrm{g} \mathrm{TSS} \mathrm{m}^{-2}$ (ANDREOTTOLA et al., 2003) and $5 \mathrm{~g} \mathrm{VSS} \mathrm{m}^{-2}$ (HONG-BIN et al., 2007).

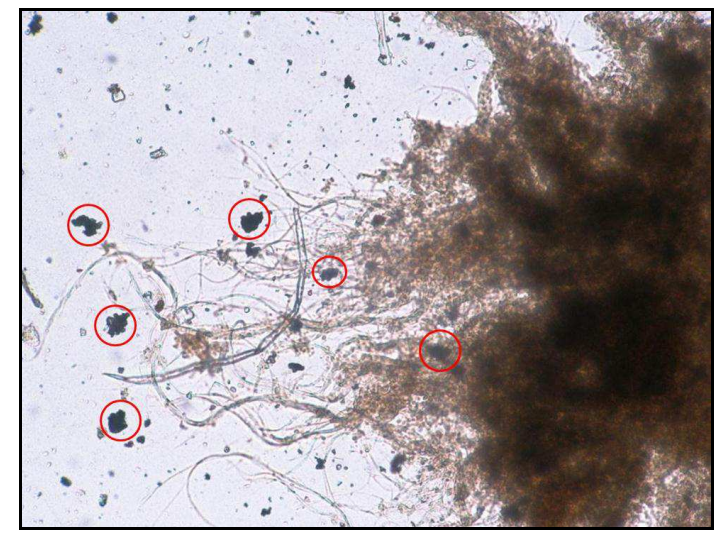

Figure 4. microscopic view of the biological flake adhered to the carriers
What remains to be analyzed in light of the results of the Table above is the ratio VSS/TSS obtained based on average values, reaching an average value of 0.69 , which indicates that much of the $\mathrm{ABF}$ is active biomass, i.e., decomposing microorganisms. However, in comparison to the results reported by Jahren et al., (2002), equal to 0.91, the data obtained are much lower. This may be justified because of the high amount of fiber found in the biomass adhered to the carriers, as observed in the microscopic analysis performed and illustrated in Figure 4, reducing, therefore, the area for adhesion of active biomass.

It is important to highlight that at no time during this study period was observed the clogging/fouling on the carriers.

\subsection{Performance Evaluation}

Table 2 shows descriptive statistics of the achieved results based on the following parameters: ${ }_{\mathrm{sol}} \mathrm{COD},{ }_{\mathrm{sol}} \mathrm{BOD}_{5}$, TOC and relation COD/BOD. 
Table 2. Results of process monitoring $\left(m g L^{-1}\right)$

\begin{tabular}{|c|c|c|c|c|c|c|c|c|c|c|}
\hline \multirow{2}{*}{\multicolumn{2}{|c|}{ Parameter }} & \multirow{2}{*}{ No. of tests } & \multirow{2}{*}{ Average } & \multirow{2}{*}{$\begin{array}{l}\text { Standard } \\
\text { Deviation }\end{array}$} & \multirow{2}{*}{$\begin{array}{l}\text { Coefficient of } \\
\text { Variation }\end{array}$} & \multicolumn{5}{|c|}{ Percentiles } \\
\hline & & & & & & 10 & 25 & 50 & 75 & 90 \\
\hline \multirow{3}{*}{${ }_{\text {sol }} \mathrm{COD}$} & Inf & 41 & 1384 & 243 & 0,18 & 1045 & 1257 & 1436 & 1530 & 1625 \\
\hline & Eff & 41 & 898 & 214 & 0,24 & 740 & 805 & 913 & 1060 & 1133 \\
\hline & $\operatorname{Ef}(\%)$ & 41 & 35 & 13 & 0,37 & 22 & 24 & 37 & 43 & 47 \\
\hline \multirow{3}{*}{${ }_{\text {sol }} \mathrm{BOD}_{5}$} & Inf & 11 & 603 & 144 & 0,24 & 375 & 604 & 642 & 682 & 717 \\
\hline & Eff & 11 & 270 & 106 & 0,39 & 152 & 211 & 277 & 325 & 400 \\
\hline & Ef $(\%)$ & 11 & 56 & 13 & 0,23 & 38 & 52 & 59 & 64 & 66 \\
\hline \multirow{3}{*}{ TOC } & Inf & 13 & 556 & 89 & 0,16 & 422 & 558 & 590 & 595 & 616 \\
\hline & Eff & 13 & 315 & 129 & 0,41 & 197 & 235 & 264 & 355 & 516 \\
\hline & $\operatorname{Ef}(\%)$ & 13 & 44 & 19 & 0,43 & 16 & 42 & 51 & 57 & 58 \\
\hline \multicolumn{2}{|c|}{ COD/BOD Inf. } & 14 & 2,3 & 0,3 & 0,13 & 1,9 & 2,1 & 2,2 & 2,4 & 2,7 \\
\hline
\end{tabular}

Box-Whiskers graphs of Figures 5 and 6 demonstrate respectively the behavior of the process in relation to the removal of solCOD and solBOD 5 and TOC through the influent and effluent concentration and removal efficiency.

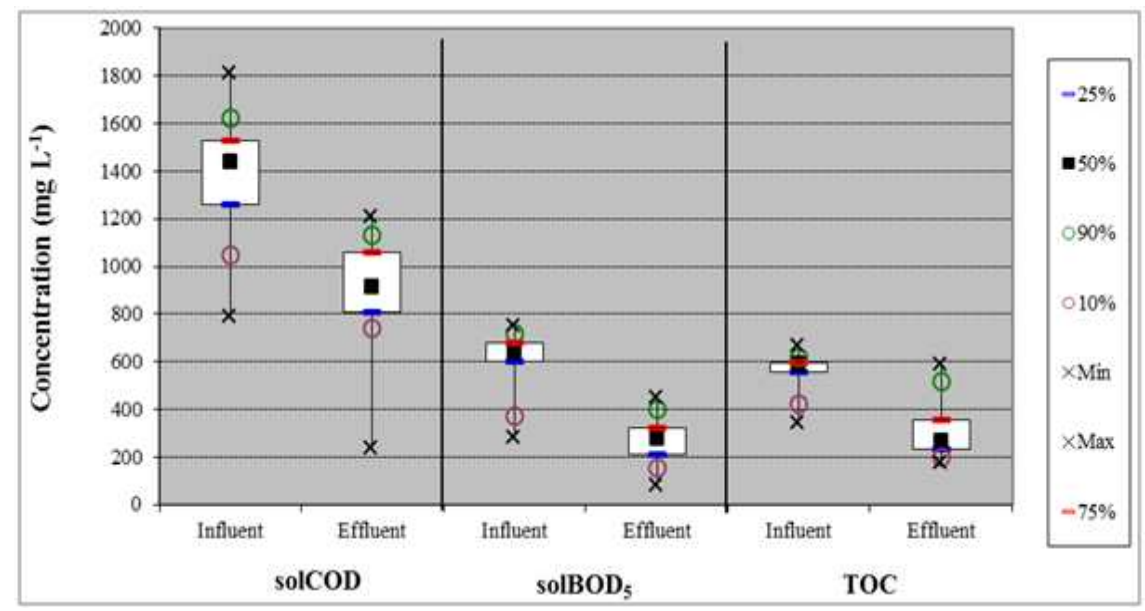

Figure 5. Box-Whiskers graph of influent and effluent concentration of ${ }_{\text {sol }} C O D_{\text {sol }} B O D_{5}$ and TOC

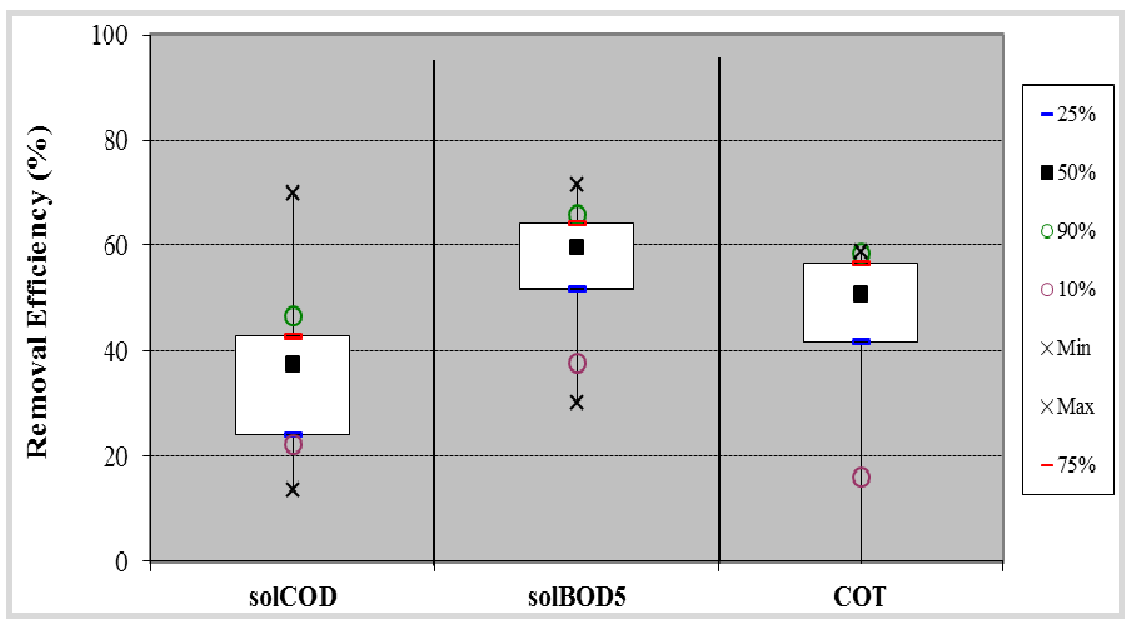

Figure 6. Box-Whiskers graph of removal efficiency of solCOD, solBOD 5 and TOC

For the operating conditions imposed on the unit,

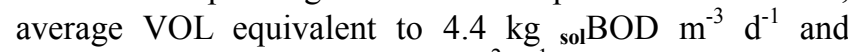
average SOL of $43.8 \mathrm{~g} \mathrm{sol}_{\text {soD m}} \mathrm{m}^{-2} \mathrm{~d}^{-1}$ and, mainly, average temperature of $44{ }^{\circ} \mathrm{C}$, it was observed that the MBBR process provided average concentration of ${ }_{\text {sol }} \mathrm{BOD}_{5}$ effluent of $270 \mathrm{mg} \mathrm{L}^{-1}$, corresponding to a good removal efficiency average of $56 \%$.
Taking as reference the experiment conducted by Jahren et al., (2002), where they worked in thermophilic conditions and obtained removal efficiencies of ${ }_{\text {sol }}$ BOD 70 to $75 \%$, these values can be justified due to the higher percentage of carriers and HRT, 58\% and 14 to 30 hours, respectively, and these values are much higher than the values obtained in this experiment. 
It can also be observed, according to Table 2, that the average ratio $\mathrm{COD} / \mathrm{BOD}$ of the feeding influent was 2.3, indicating a good biodegradability and much smaller when is compared to the full-scale MBBR system installed in the company, which was equal to 6.0 .

It is also important to note that during a period of 10 days, there was a problem in the effluent booster pump, causing a hydraulic shock of load in the pilot reactor. However, once solved the problem and resuming the monitoring process, it was realized that there was loss of process efficiency, demonstrating excellent system stability.

\subsection{Final Considerations}

It is highlighted in relation to the operating and control parameters that:

- VOL and SOL parameters were remained within the rates indicated in the literature;

- The average DO value was, in principle, the recommended lower limit, equal to $2 \mathrm{mg} \mathrm{L}^{-1}$;

- The $\mathrm{pH}$ maintained constant throughout the monitoring period indicating good stability of the process.

Such results lead us to reflect on how the environmental issue has been addressed in terms management organizations in general. It is extremely important that the generated effluents should be considered as products of their production process. Therefore, this matter must be present in the own design of the production process, for the wastewater treatment may occur efficiently and sustainably.

Even if the decision of wastewater treatment is postponed, the production process ever designed, it is observed that companies tend to choose the technology before a detailed analysis of technical and economic feasibility, which leads to design decisions little applied to the reality of the company and/or with financial investments too costly.

\section{Conclusions}

Firstly, this work promoted the quantification of adhered biomass, even through a quite simple analysis, achieving a high $\mathrm{ABF}$, equal to $14.6 \mathrm{~g} \mathrm{VSS} \mathrm{m}^{-2}$, which characterizes a carriers with a high amount of microorganisms adhered.

Regarding the performance of the pilot plant, it is highlighted the stability of organic substance removal (BOD, TOC and COD), i.e., using only one reactor, it is recommended the use of three or more serial reactors, and considering that the reactor worked under thermophilic conditions (better performance is expected in mesophilic conditions) shows that the temperature was not a limiting factor.

Moreover, when analyzing the results, it can be inferred that the MBBR system contained in the wastewater treatment plant of Company Suzano probably will not achieve the efficiency and stability of design. Since it does not meet the basic requirement for its use, namely employed as a first unit of biological treatment.

\section{Acknowledgments}

To the companies of Suzano Papel e Celulose and MMA Consultoria Ambiental.

\section{References}

[1] ANDREOTTOLA, G.; FOLADORI, P.; GATTI, G.; NARDELLI, P.; PETTENA, M.; RAGAZZI, M. (2003): Upgrading of a small overloaded activated sludge plant using a MBBR system. Journal of Environmental Science and Health, Part A: Toxic/Hazardous Substances Environmental Engineering, 38 (10) 2317-2328.

[2] ASSOCIAÇÃO BRASILEIRA DE NORMAS TÉCNICAS (ABNT) - NBR-12.209. (2012): Elaboração de Projetos Hidráulico-sanitários de Sistemas de Tratamento de Esgotos Sanitários.

[3] APHA - AMERICAN PUBLIC HEALTH ASSOCIATION: Standard Methods for the Examination of Water and Wastewater. $21^{\text {th }}$ ed. Washington: Public Health Association. 2005.

[4] BROCH-DUE, A.; ANDERSEN, R.; OPHEIM, B. (1997): Treatment of integrated newsprint mill wastewater in moving bed biofilm reactors. Water Science and Technology. 35 (2-3) 173-180.

[5] HONG-BIN, Y.; XIE, Q.; YUN-ZHENG, D. (2007): Medium-Strength Ammonium Removal Using a Two-Stage Moving Bed Biofilm Reactor System. Environmental Engineering Science. Vol 24 (05) 295-601.

[6] JAHREN, S. J.; RINTALA, J. A.; ODEGAARD, H. (2002): Aerobic moving bed biofilm reactor treating thermomechanical pulping whitewater under thermophilic conditions. Water Research. 36, 1067-1075.

[7] MINEGATTI, D. V. O. (2008): Caracterização dos Parâmetros de Controle e Avaliação de Desempenho de um Reator Biológico com Leito Móvel (MBBR). Dissertação de mestrado. Departamento de Engenharia Civil Universidade Federal do Rio de Janeiro.

[8] MORAIS, A. A.; MOUTEER, A. H.; SILVEIRA, D. S. A. (2007): Melhoria na eficiência de tratamento de efluentes de celulose Kraft de eucalipto pela combinação de ozonização e tratamento biológico. O Papel. 67 (12) 83-95.

[9] PASTORELLI, G.; ANDREOTTOLA, G. (1997): Pilot-plant experimental with moving-bed biofilm reactors. Waste Science and Tecnhology. Vol. 36 (1) 43-50.

[10] RUSTEN, B.; MATTSSON, E.; BROCH-DUE, A.; WESTRUM, T. (1994): Treatment of pulp and paper industry wastewater in novel moving bed biofilm reactors. Water Science and Technology. 30 (3) 161-171. 